\title{
AEROMAGNETIC MAP OF THE YELLOWSTONE CANYON QUADRANGLE, APACHE COUNTY \\ ARIZONA
}

By

F. C. Frischknecht, F. A. Petrafeso, and others

GEOPHYSICAL INVESTIGATIONS

MAP GP-405

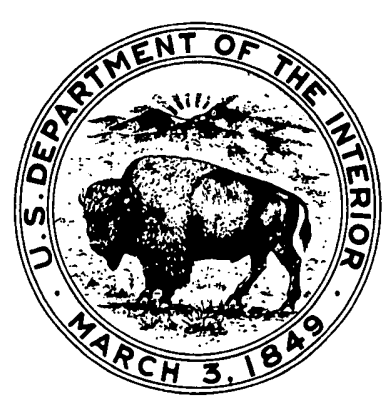

PUBLISHED BY THE U. S. GEOLOGICAL SURVEY 